Proceedings

\title{
The Role of Motivation in the Development of Transversal Competences ${ }^{\dagger}$
}

\author{
María Isabel Rodríguez-Cáceres ${ }^{1, *}$, Mónica Palomino-Vasco ${ }^{1}$ and María Victoria Gil Álvarez ${ }^{2}$ \\ 1 Department of Analytical Chemistry, University of Extremadura, 06006 Badajoz, Spain; monicapv@unex.es \\ 2 Department of Organic and Inorganic Chemistry, University of Extremadura, 06006 Badajoz, Spain; \\ vgil@unex.es \\ * Correspondence: maribelro@unex.es; Tel.: +34-924-289300 \\ + Presented at the 2nd Innovative and Creative Education and Teaching International Conference \\ (ICETIC2018), Badajoz, Spain, 20-22 June 2018.
}

Published: 31 October 2018

\begin{abstract}
The experience was carried out with the students of the optional subject "Wine and Health", taught in 4th year of Degree of Oenology. This Degree has a low number of students, due to that, in the first year of teaching (2013/14) only three students enrolled in the subject, so we considered it was necessary to do something "different" to motivate students to enroll in this subject. This was carried out by inviting them to do a literature review on some topics, such as the relationship between moderate wine intake and Alzheimer's, Parkinson's, Cancer or Allergy. In addition, they had to make an audiovisual presentation and expose it in the Conference of Viticulture and Oenology that are celebrated in Almendralejo (Badajoz, Spain), every year at the beginning of May. In general, after five years it has been observed that this methodology has increased the interest of students for this subject, which is reflected in more students in class, more class attendance and great interest. In addition, they have developed transversal skills such as public speaking, which has provided them with security and will probably be useful when conducting job interviews.
\end{abstract}

Keywords: motivation; transversal competences; public speaking

\section{Introduction}

The Degree in Oenology is taught in the Faculty of Sciences of the University of Extremadura since the academic year 2010/11. In 2013/14, the fourth course began, and the optional subject "Wine and Health" was offered for the first time. This subject has six credits divided into $42 \mathrm{~h}$ of large group, $15 \mathrm{~h}$ of seminar and $3 \mathrm{~h}$ of ECTS tutoring. A characteristic of this degree is that the first two courses are part of a joint training plan with the Degree in Chemistry. Another characteristic, quite striking, is the low number of students it has (see Table 1).

Table 1. Students enrolled in the Degree in Oenology and in the optional subject "Wine and Health".

\begin{tabular}{|c|c|c|c|c|c|c|c|}
\hline & 2011/12 & 2012/13 & 2013/14 & 2014/15 & 2015/16 & 2016/17 & 2017/18 \\
\hline $\begin{array}{l}\text { Number of new students per } \\
\text { academic year }\end{array}$ & 7 & 16 & 13 & 19 & 19 & 15 & 9 \\
\hline $\begin{array}{c}\text { Number of students enrolled } \\
\text { in "Wine and Health" }\end{array}$ & & & 3 & 5 & 6 & 6 & 3 \\
\hline Number of graduate students & & & & 1 & 4 & 4 & \\
\hline
\end{tabular}


In the first year of teaching "Wine and Health" (2013/14) only three students enrolled in the option, so we considered it necessary to do something "different" to motivate students to enroll in this optional subject. As can be seen in Table 1, the number of students increased in the following years, which shows that the subject is motivating. Since there are so few students, the transmission of information is word of mouth and this has brought with it a considerable increase of students in this optional subject.

\section{Experimental}

In order to achieve the motivation of the students, it was proposed that during the $15 \mathrm{~h}$ of the seminar they did a literature review on important health issues, such as, for example, the relationship between moderate wine intake and Alzheimer's, Parkinson's, Cancer or Allergies. In the first seminar they were taught to carry out bibliographic searches through the university library, since from there they have access to a multitude of scientific journals through various platforms, such as www.sciencedirect.com.

Once the basic notions were explained, the students, in small groups (2-3), chose the disease they wanted to study and proceeded to carry out the bibliographic search. As an example, in Table 2, the results found for the search of the relationship that exists between wine and its components with Alzheimer's disease are shown. As can be seen in Table 2, when "Alzheimer" was used as keyword, more than 200,000 citations appear, so it is necessary to refine the search criteria.

Table 2. Number of articles found in the bibliographic search of Alzheimer's disease using different keywords.

\begin{tabular}{cc}
\hline Keywords & No. of Cites \\
\hline Alzheimer & 210,770 \\
Alcohol and Alzheimer & 27,696 \\
Polyphenols and Alzheimer & 4504 \\
Wine and Alzheimer & 3630 \\
Resveratrol and Alzheimer & 2901 \\
Catechin and Alzheimer & 1887 \\
\hline
\end{tabular}

"Wine" together with its components "resveratrol", "catechin" and "alcohol", among others, were used as keywords. With these new keywords, the number of articles decreases, but it is still very high. So it was decided to take the most relevant articles in the title or abstract containing the keywords. Finally, 79 references were selected, since the work was limited to a maximum of 10 pages (without including references, figures or tables).

Then, once the articles were selected, the most relevant information had to be extracted and write a summary. To store all the selected articles and work with them, Google Apps were used, mainly Google Drive and Google Docs. In addition, they had to make an audiovisual presentation, but instead of exposing the work in class, students were given the opportunity to attend a Conference on Viticulture and Oenology that is held every year at the beginning of May in Almendralejo (Badajoz).

\section{Results and Discussion}

As a result of this work methodology, first, the number of students enrolled in the subsequent courses increased as can be seen in Table 1. In these five years only two students have suspended and repeated courses, this has been due to the lack of attendance to class. The rest of the students have had an attendance close to $100 \%$.

It was clearly observed that the students developed several transversal competences such as the capacity for synthesis, organization, and mainly written and oral expression. For them it was very motivating to expose it in the Conference on Viticulture and Oenology, since in addition to practicing the public speaking before an unknown public (something that gives them terror) they 
could add their attendance to a conference to their curriculum. The papers presented are of high quality and their implementation has allowed students to deepen their knowledge of a disease in which moderate intake of wine can have some beneficial effect.

As can be seen in Figure 1, the room where the Conference takes place is quite small with space for about 30-40 people, which makes the students feel comfortable when making the oral presentation. The Conference requires an oral presentation of the work as an indispensable condition for published it afterwards in a book. In Figure 2 the posters of the last four years of the Conference of Viticulture and Oenology celebrated in Almendralejo (Badajoz, Spain) are shown.

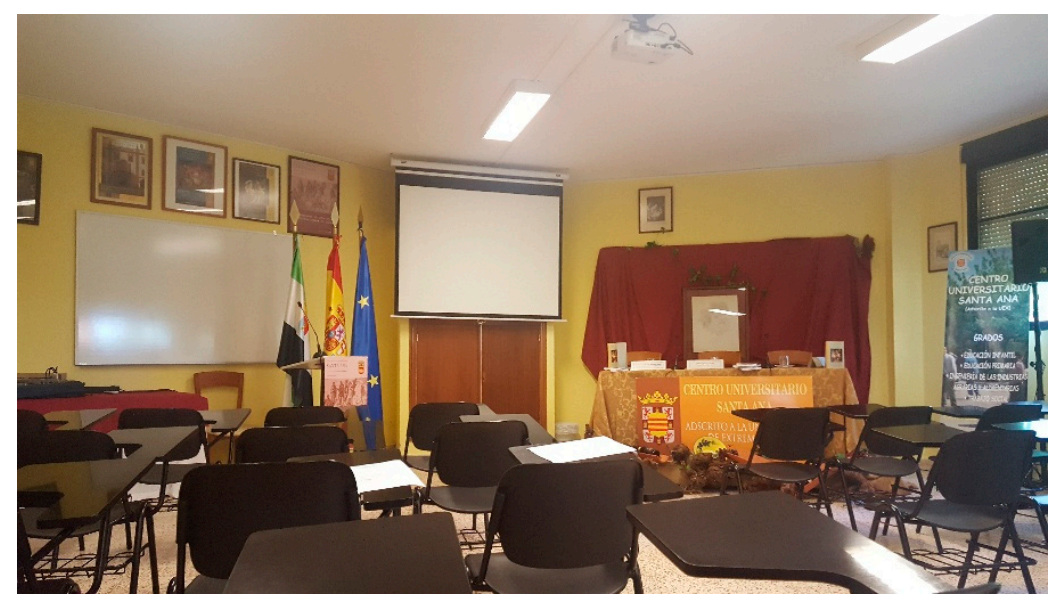

Figure 1. Room where the Conference of Viticulture and Oenology takes place.
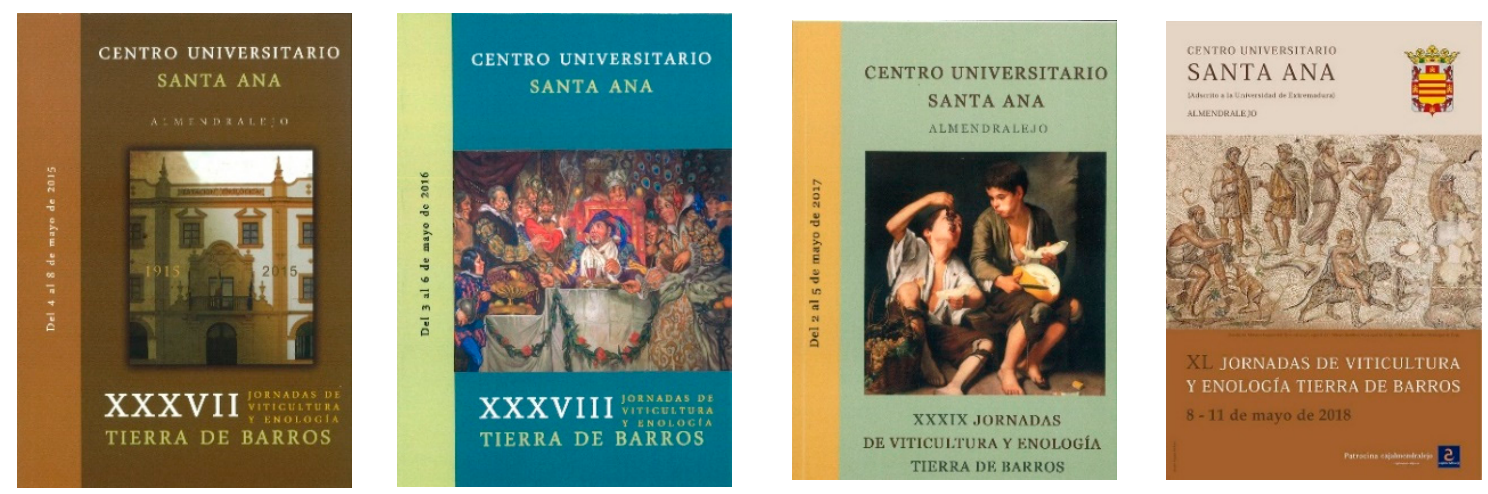

Figure 2. Posters of the last four years of the Conference of Viticulture and Oenology celebrated in Almendralejo (Badajoz, Spain).

The themes presented were:

- 2015: Review of the beneficial effects of wine polyphenols on Parkinson's disease [1] (see Figure 3).

- 2016: Review of studies on the use of resveratrol in cancer chemoprevention [2].

- 2017: Review of studies on the use of wine in Alzheimer's disease [3].

- 2018: Allergens in wine [4]. 


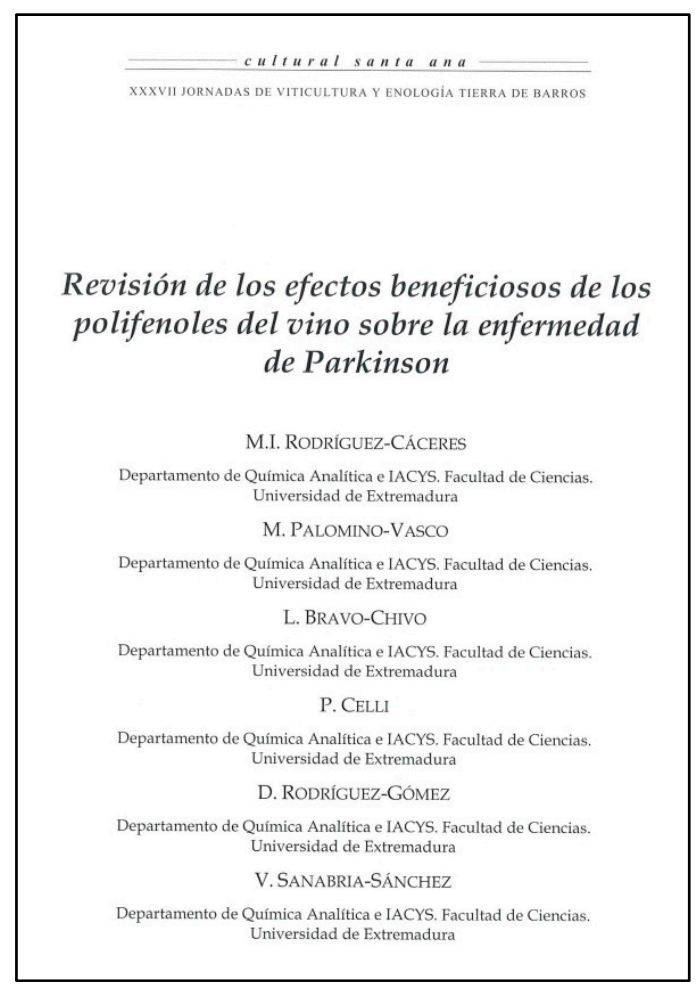

Figure 3. First page of the review presented in 2015.

\section{Conclusions}

In general, after five years of teaching it has been observed that this methodology has increased the interest of the students for this subject, which is reflected in a greater number of students, greater attendance to class and a great interest. In addition, they have developed transversal skills such as public speaking, which has provided them with security and will probably be useful when conducting job interviews.

Conflicts of Interest: The authors declare no conflict of interest.

\section{References}

1. Rodríguez-Cáceres, M.I.; Palomino-Vasco, M.; Bravo-Chivo, L.; Celli, P.; Rodríguez-Gómez, D.; Sanabria-Sánchez, V. Revisión de los efectos beneficiosos de los polifenoles sobre la enfermedad de Parkinson. In Proceedings of the XXXVII Jornadas de Viticultura y Enología Tierra de Barros, Almendralejo, Spain, 4-8 May 2015; pp. 117-137, ISBN 978-84-7930-104-X.

2. Rodríguez-Cáceres, M.I.; Monzú-García, A.B.; Viviens Martín, B.; Durán Gutiérrez, I.; Vílchez Moya, A. Revisión de los estudios sobre el uso del resveratrol en la quimioprevención del cáncer. In Proceedings of the XXXVIII Jornadas de Viticultura y Enología Tierra de Barros, Almendralejo, Spain, 3-6 May 2016; pp. 129-143, ISBN 978-84-7930-106-6.

3. Rodríguez-Cáceres, M.I.; Monzú-García, A.B.; Viviens Martín, B.; Durán Gutiérrez, I.; Vílchez Moya, A. Revisión de los estudios sobre el uso del vino en la enfermedad de Alzheimer. In Proceedings of the XXXIX Jornadas de Viticultura y Enología Tierra de Barros, Almendralejo, Spain, 2-5 May 2017; pp. 93118, ISBN 978-84-7930-107-4.

4. Rodríguez-Cáceres, M.I.; Palomino-Vasco, M.; Pardo-Botello, M.R.; Campos García, M.P.; Rascón Gutiérrez, F.; Rodríguez Martínez, H.L. Alérgenos en el vino. In Proceedings of the XL Jornadas de Viticultura y Enología Tierra de Barros, Almendralejo, Spain, 8-11 May 2018.

(C) 2018 by the authors. Licensee MDPI, Basel, Switzerland. This article is an open access article distributed under the terms and conditions of the Creative Commons Attribution (CC BY) license (http://creativecommons.org/licenses/by/4.0/). 